\title{
Mechanisms of Clostridium tyrobutyricum removal through natural creaming of milk: A microscopy study
}

\author{
P. D’Incecco, ${ }^{\star 1}$ F. Faoro,† T. Silvetti,‡ K. Schrader,§ and L. Pellegrino* \\ *Department of Food, Environmental and Nutritional Sciences, and \\ †Department of Agricultural and Environmental Sciences-Production, Landscape, Agroenergy, University of Milan, 20133 Milan, Italy \\ †Institute of Sciences of Food Production-Italian National Research Council, 20133 Milan, Italy \\ §Max Rubner-Institut, Federal Research Institute of Nutrition and Food, 24103 Kiel, Germany
}

\begin{abstract}
Clostridium tyrobutyricum is the main spoilage agent of late blowing defect (LBD) in Grana Padano and Parmigiano-Reggiano cheeses; LBD is characterized by openings and holes and is sometimes accompanied by cracks and an undesirable flavor. Even a very few spores remaining in the cheese curd may cause LBD; thus, it is essential to eradicate them during milk natural creaming. By this process, most of the bacteria, somatic cells, and spores rise to the top of the milk, together with the fat globules, and are removed with the cream. Previous studies suggested that milk immunoglobulins mediate the interactions between fat globules and bacteria that occur upon creaming but no direct evidence for this has been found. Moreover, other physical chemical interactions could be involved; for example, physical entrapment of spores among globule clusters. To maximize the efficiency of the natural creaming step in removing $\mathrm{Cl}$. tyrobutyricum, it is essential to understand the nature of spore-globule interactions. With this aim, raw milk was contaminated with spores of $C l$. tyrobutyricum before going to creaming overnight at $8^{\circ} \mathrm{C}$, after which spore and bacteria removal was $>90 \%$. The obtained cream was analyzed by light interference contrast and fluorescence microscopy and by transmission electron microscopy (TEM). Results showed that most of the vegetative cells and spores, which were stained with malachite green before addition to milk, adhered tightly to the surface of single fat globules, the membranes of which appeared heterogeneous when stained with the fluorescent dye $\mathrm{DilC}_{18}(3)$-DS. Using the same dye, we observed transient and persistent interactions among globules, with formation of clusters of different sizes and partial coalescence of adhering membranes. Transmission electron microscopy examination of replicates of freeze-fractured cream allowed us to observe tight
\end{abstract}

Received March 3, 2015.

Accepted April 11, 2015.

${ }^{1}$ Corresponding author: paolo.dincecco@unimi.it adhesion of spores to fat globules. Ultrathin sections revealed that this adhesion is mediated by an amorphous, slightly electron-opaque material, sometimes granular in appearance. Bacteria also adhered to different fat globules, linking them together, which suggests that adhesion was strong enough to maintain a stable contact. Although we cannot exclude physical entrapment of bacteria among fat globule clusters, we show for the first time that most of the bacteria are adhered to fat globules by an electron-opaque material whose nature has yet to be determined. Immunoglobulins are certainly the best candidates for adhesion but other compounds may be involved.

Key words: Clostridium tyrobutyricum, spore, milk natural creaming, fat globule, transmission electron microscopy

\section{INTRODUCTION}

Traditionally, Italian cow milk is mostly processed into typical products bearing the Protected Designation of Origin (PDO; European Union, 2012), such as the long-ripened Grana Padano and Parmigiano-Reggiano cheeses. The consolidated manufacturing process of these cheeses involves technological treatments that give the finished product appreciable quality and specific features. Natural (static) creaming performed during the preparation of cheese milk is one the most effective among these treatments. In addition to decreasing the fat content to 2.2 to $2.4 \%$ and thus standardizing the fat-to-casein ratio, which is important for development of the unique grainy cheese texture, this process has a substantial effect on the hygienic quality of the milk. In fact, during the 8- to 10-h creaming process, most of the bacteria, somatic cells, and spores rise to the top of the milk, together with the fat globules, and are removed with the cream (Bottazzi, 1971; Abo-Elnaga et al., 1981). This cleaning effect is mostly relevant with respect to spores. Spores of some Clostridium species can cause the late blowing defect (LBD) in the resulting hard and semi-hard cheeses, as characterized by openings and holes, sometimes accompanied by cracks and 
an undesirable flavor. In fact, outgrowth of clostridial spores leads to butyric acid fermentation, producing mainly butyric acid, carbon dioxide, and hydrogen (Bergère and Lenoir, 2000). Clostridium tyrobutyricum is the main spoilage agent responsible for LBD in Grana Padano and Parmigiano-Reggiano (Bottazzi and Dellaglio, 1970; Bosi et al., 1984; Bassi et al., 2009), whereas other species, including Clostridium sporogenes, Clostridium beijerinckii, and Clostridium butyricum, have been shown to contribute to development of the defect in other hard and semi-hard cheeses (Le Bourhis et al., 2007; Cremonesi et al., 2012). Although LBD is a long-standing issue, very well known by cheese manufacturers, its eradication is difficult because Clostridium spores are ubiquitous. Several tools have been proposed to prevent LBD, including (1) use of additives such as nitrate, (2) milk bactofugation or microfiltration, or (3) addition of inhibiting strains of lactic acid bacteria (Lodi, 1990; Stadhouders, 1990a,b; van den Berg et al., 2004). However, according to product specifications, most of these tools are not allowed or are explicitly forbidden in PDO cheese manufacturing. Currently, lysozyme is the only bacteriostatic agent that is allowed in Grana Padano cheese. This situation indicates the technological relevance of maximizing efficiency of the natural creaming step in spore removal. Detailed studies were conducted previously on the natural creaming of milk and the phenomena involved. Some of these studies suggested that native bovine immunoglobulins mediate the interactions between fat globules and bacteria that occur upon gravity separation, leading to entrapment of bacteria in the cream (Stadhouders and Hup, 1970; Bottazzi and Zacconi, 1980; Euber and Brunner, 1984; Frenyo et al., 1986; Parham, 2009). Recently, Caplan et al. (2013) and Geer and Barbano (2014a) confirmed that immunoglobulins may be one of the factors necessary for removal of somatic cells and bacterial spores from milk during gravity separation of fat. However, direct evidence of a role for immunoglobulins in this process is still lacking. The complex structure of milk fat globule membrane (MFGM) has been investigated in numerous studies, and both light and confocal microscopy observations provide evidence of its great heterogeneity (Evers, 2008; Evers et al., 2008; Lopez et al., 2010, 2011). Transmission electron microscopy (TEM) has also been used as a tool to study the MFGM in different dairy products (Resmini et al., 1984; Schmidt and Buchheim, 1992; Zamora et al., 2012). Nevertheless, until now, no ultrastructural studies have been carried out to investigate interactions between fat globules and bacterial cells or spores in milk or cream, possibly because the high water content of these matrices represents a difficult task for electron microscopy (Silva et al., 2015).
In this work, we experimented with different microscopy techniques, including TEM, to study the interactions occurring among fat globules and $\mathrm{Cl}$. tyrobutyricum vegetative cells and spores upon natural creaming. The aim was to understand whether vegetative cells and spores in the cream establish specific interactions with fat globules or mostly remain in the cream by physical entrapment in fat globule clusters. To reach this goal, a suitable procedure was first set up to prepare experimental samples. Raw milk was intentionally contaminated with spores of $\mathrm{Cl}$. tyrobutyricum and submitted to gravity separation of fat.

\section{MATERIALS AND METHODS}

\section{Chemicals}

The fluorescent probe $\mathrm{DilC}_{18}(3)$-DS (1,1'-dioctadecyl$3,3,3^{\prime}, 3^{\prime}$-tetramethylindocarbocyanine-5, $5^{\prime}$-disulfonic acid) was purchased from Molecular Probes (Eugene, OR). Glutaraldehyde, paraformaldehyde, cacodylate buffer, and osmium tetroxide were purchased from Agar Scientific (Stansted, UK). Green malachite and calcofluor were purchased from Sigma-Aldrich (St. Louis, MO). Microbiological analyses were performed using the following chemicals: Ringer and Reinforced Clostridial Medium (RCM) from Scharlau Microbiology (Barcelona, Spain), skim milk powder, Anaerocult A, and sodium lactate and sodium acetate from VWR (Leuven, Belgium), yeast extract from Formedium (Hunstanton, UK), cysteine from Sigma Aldrich, and paraffin/vaseline mixture from Sacco S.r.l. (Cadorago, Italy). Water purified using Milli-Q system (Millipore Corp., Bedford, MA) was used.

\section{Samples of Raw Milk}

All samples were prepared from raw bulk milk collected from a local herd of 120 Holstein dairy cows immediately after the morning milking. Aliquots of 500 $\mathrm{mL}$ of milk were taken before refrigeration and brought to the laboratory within $1 \mathrm{~h}$ after milking.

\section{Bacterial Strains and Spore Suspension Production}

Clostridium tyrobutyricum DSMZ 2637 provided by the Deutsche Sammlung Von Mikroorganismen und Zellkulturen (Braunschweig, Germany) was used for all experiments. The strain was routinely cultured in RCM broth and incubated at $37^{\circ} \mathrm{C}$ in anaerobic jars equipped with Anaerocult A. Spore suspensions were obtained by adapting the protocol described by Bassi et al. (2009). Spores were prepared by inoculating $1 \%$ of 24 -h culture of $\mathrm{Cl}$. tyrobutyricum culture in a bottle holding $400 \mathrm{~mL}$ of RCM broth. The culture was maintained anaerobi- 
cally for $4 \mathrm{~d}$ at $37^{\circ} \mathrm{C}$ and for a further $15 \mathrm{~d}$ at room temperature. Then, spores were harvested, centrifuged $\left(8,000 \times g\right.$ at $4^{\circ} \mathrm{C}$ for $\left.10 \mathrm{~min}\right)$, washed (3 times with sterile water), and finally stored in water at $4^{\circ} \mathrm{C}$ until use. The presence of spores was evaluated by phase contrast microscopy and quantified by using a Burker's chamber; the spore count ranged from 3.0 to $3.2 \times 10^{6}$ $\mathrm{cfu} / \mathrm{mL}$.

\section{Preparation of Contaminated Cream Samples}

Aliquots of $25 \mathrm{~mL}$ of raw milk were transferred into 25-mL screw-cap tubes, each with $1 \mathrm{~mL}$ of spore suspension added, prepared as described above, and carefully mixed by gentle inversions. Alternatively, spores were previously stained (as indicated below) with green malachite or calcofluor to be easily recognizable by light or fluorescence microscopy. The tubes were kept at $8^{\circ} \mathrm{C}$ overnight and the cream layer that rose to the top of the milk was gently removed by using a pipette. By this procedure, 2 different samples were obtained: the cream taken from the top of the test tube and the skim milk below the cream.

\section{Evaluation of Anaerobic Spore Counts in Cream and Skim Milk}

Spores of anaerobic clostridia were determined by the most probable number (MPN) technique in cream and skim milk samples. Aliquots $(1 \mathrm{~mL})$ from serial dilutions of samples prepared using sterile Ringer solution were inoculated into 5 tubes containing $5 \mathrm{~mL}$ of reconstituted $(10 \% \mathrm{wt} / \mathrm{vol})$ skim milk that was sterilized and supplemented with yeast extract $(1.0 \% \mathrm{wt} /$ vol), sodium lactate $(3.36 \% \mathrm{wt} / \mathrm{vol})$, sodium acetate $(1 \% \mathrm{wt} / \mathrm{vol})$, and cysteine $(0.2 \% \mathrm{wt} / \mathrm{vol})$ and sterilized. Each tube was overlaid with $1.5 \mathrm{~mL}$ of sterile melted paraffin:vaseline mixture $(1: 1, \mathrm{wt} / \mathrm{wt})$ and heated at $80^{\circ} \mathrm{C}$ for $10 \mathrm{~min}$ to kill vegetative cells. Incubation was carried out at $37^{\circ} \mathrm{C}$ for $7 \mathrm{~d}$ and daily inspected for gas production. The MPN counts were expressed as spores per milliliter. Two trials were performed using 3 and 5 dilutions, respectively. Five tubes were used for all of the dilution series.

\section{Light and Fluorescence Microscopy}

For light microscopy, spores were stained with malachite green (adapted from Schaeffer and Fulton, 1933). Two hundred microliters of malachite green solution ( $5 \%$ in water, wt/vol) was added to an aliquot of $1 \mathrm{~mL}$ of spore suspension and mixed. The mixture was heated by immersion in a boiling water bath for $2 \mathrm{~min}$ and washed 5 times with distilled water by centrifugation.
Cream samples contaminated with previously stained spores were layered on microscope slides and examined with an Olympus BX optical microscope (Tokyo, Japan) equipped with Nomarski interference contrast and QImaging Retiga camera (Surrey, BC, Canada). For fluorescence microscopy of fat globules, an aqueous solution of the lipophilic probe $\operatorname{DilC}_{18}(3)-\mathrm{DS}(1 \mathrm{mg} / \mathrm{mL})$ was added to raw milk at a final probe concentration of $10 \mu \mathrm{g} / \mathrm{mL}$. The staining conditions tested in milk were either $40^{\circ} \mathrm{C}$ for $4.5 \mathrm{~h}$ or $8^{\circ} \mathrm{C}$ overnight, and the obtained cream samples were examined by UV light (excitation wavelength $=570 \mathrm{~nm}$, emission wavelength $=590 \mathrm{~nm})$, with the same microscope described above. The emission wavelength of the probe was $570 \mathrm{~nm}$.

To stain the spores, $100 \mu \mathrm{L}$ of calcofluor $(1 \mathrm{~g} / \mathrm{L}$ in water) was added to $1 \mathrm{~mL}$ of spore suspension and, after 5 min of incubation, the spores were washed 3 times with distilled water by centrifugation. When calcofluorstained spores were added to the raw milk, the derived cream samples were examined by UV light at excitation wavelength $=400 \mathrm{~nm}$ and emission wavelength $=420$ $\mathrm{nm}$ to detect both spore and fat globule fluorescence.

\section{Transmission Electron Microscopy}

To investigate spore-fat globule interactions at the ultrastructural level, both freeze-fractured replicates and ultrathin sections of cream contaminated with spores were observed by TEM.

For freeze-fractured samples, cream was first cryoprotected by mixing $1 \mathrm{~mL}$ of sample with $1 \mathrm{~mL}$ of glycerol $(60 \%, \mathrm{wt} / \mathrm{wt})$ and then cryofixed by immersion of small droplets into melting Freon $22\left(-160^{\circ} \mathrm{C}\right)$. Specimens were freeze-fractured at $-120^{\circ} \mathrm{C}$ with a BAL-TEC BAF 400 unit (Balzers, Liechtenstein). Freeze-fractured specimens were replicated by layering $\mathrm{Pt} / \mathrm{C}$ and $\mathrm{C}$ by electron-gun evaporation. The replicas were cleaned in concentrated sodium hypochlorite and in acetone with repeated intermediate rinses in distilled water. Specimen replicas were examined with an FEI Tecnai 10 (Eindhoven, the Netherlands) TEM operating at $80 \mathrm{kV}$.

For preparation of the ultrathin sections, $1.5 \mathrm{~mL}$ of fixative solution (glutaraldehyde 1\%, paraformaldehyde $4 \%$ in cacodylate buffer, wt/vol) was added to a 0.5 $\mathrm{mL}$ aliquot of cream. The mixture was kept for $2 \mathrm{~h}$ at room temperature and then mixed with $2 \mathrm{~mL}$ of warm, melted $\left(35-40^{\circ} \mathrm{C}\right)$ low-temperature gelling agarose $(2 \%$ in water). The suspension was layered onto a microscope slide before it gelled, allowed to set, and then cut into $1-\mathrm{mm}^{3}$ cubes. Cubes were further fixed in the same fixative solution as above for $30 \mathrm{~min}$ at $4^{\circ} \mathrm{C}$, and then washed with cacodylate buffer for $1 \mathrm{~h}$ and post-fixed in osmium tetroxide ( $1 \%$ in water) for $2 \mathrm{~h}$. Dehydration was carried out in an ethanol series, and then samples 
were embedded in Spurr resin and cured at $60^{\circ} \mathrm{C}$ for 24 h. Ultrathin sections, 50 to $60 \mathrm{~nm}$ thick, were stained with uranyl acetate and lead citrate and examined with a Philips E208 transmission electron microscope (Aachen, Germany).

\section{RESULTS}

\section{Experimental Preparation of Contaminated Cream Samples}

The conditions adopted on a laboratory scale to obtain cream samples for our study were chosen to maintain the native properties of fat globules. The raw milk was processed within a few hours of milking, thus avoiding cooling of the milk and addition of preservatives. Furthermore, conditions similar to those adopted in the real cheese manufacturing processes of Grana Padano and Parmigiano-Reggiano were considered. We chose 25 -mL tubes to have 18 to $20 \mathrm{~cm}$ (height) of milk (Dellagio et al., 1969).

The MPN method was used to confirm the concentration of spores in the cream layer obtained by gravity separation of intentionally contaminated milk. Samples of cream and skim milk were taken from the test tubes of 2 independent experiments and analyzed for clostridial spores. In both trials, the Clostridium spp. spore count was higher in the cream sample than in the skim milk (Table 1). The cream of trial 1 contained $99.4 \%$ of the total spores detected and the cream of trial 2 contained $99.5 \%$ of total spores.

\section{MFGM and Fat Globule Interactions}

The MFGM was observed by staining with the lipophilic probe $\mathrm{DilC}_{18}(3)$-DS. As suggested by Evers (2008), we used an aqueous solution of the probe because ethanol might perturb the membrane structure by denaturing constitutive proteins. However, unlike what was reported by Evers (2008), we found that $\mathrm{DilC}_{18}(3)$-DS fully dissolved in water at the concentration of $1 \mathrm{mg} / \mathrm{mL}$. Two staining conditions were tested: $40^{\circ} \mathrm{C}$ for $4.5 \mathrm{~h}$ and $8^{\circ} \mathrm{C}$ overnight, both in darkness. Overnight staining gave the best results and confirmed that $\mathrm{DilC}_{18}(3)$-DS was located exclusively in the MFGM
(Evers, 2008; Lopez et al., 2010; Figure 1a). The MFGM fluorescence was often heterogeneous, characterized by areas that were almost nonfluorescent and others that were densely stained (Figure 1b, arrows).

To test the stability of the interactions among fat globules, the cream was progressively diluted with skim milk and observed by Nomarski interference microscopy. Two types of interactions were recorded: (1) a transient interaction in which fat globules seemed to interact weakly for a limited time during observation and then separated, and (2) a persistent interaction where globules remained consistently attached to each other. In the latter case, MFGM was not visible in the contact area of the involved fat globules, suggesting their partial coalescence (Figure 1c and 1d, arrows). Fat globule clusters were still present in the cream after $12 \times$ dilution with skim milk and, in some cases, they derived from the aggregation of at least 5 or 6 globules (Figure 1c).

\section{Interactions of Vegetative Cells and Spores with Fat Globules}

Because the concentration of fat globules in whole cream was too high to be observed directly by light microscopy, cream samples were diluted 5 times with skim milk. The dilution of the cream also allowed us to see bacterial cells and spores of $\mathrm{Cl}$. tyrobutyricum (Figure 2a), which had been stained with malachite green before addition to milk. Most of the bacteria adhered to the surface of fat globules (arrows) but it was very difficult to discriminate spores from bacterial cells, even at the highest magnification. Interestingly, bacterial adhesion occurred preferentially to single fat globules, not to globule clusters, although no information was gained on the nature of these interactions. Calcofluor staining of bacteria gave similar results, showing adhesion of bacterial cells and spores to fat globules. Calcofluor-stained spores appeared bright when inside bacterial cells. In this case, the spore was surrounded by a faint halo of ephemeral fluorescence due to the bacterium containing it (Figure 2b, arrow). We attempted to stain fat globules with $\mathrm{DilC}_{18}(3)$-DS in cream samples contaminated with calcofluor-stained spores to verify whether spore adhesion occurred in the

Table 1. Most probable number (MPN) counts of anaerobic spore-forming bacteria in milk after natural creaming

\begin{tabular}{lccccc}
\hline & \multicolumn{2}{c}{ Trial 1} & & \multicolumn{2}{c}{ Trial 2} \\
\cline { 2 - 3 } \cline { 5 - 6 } Sample & $\mathrm{MPN} / \mathrm{mL}$ & $\mathrm{MPN} \log _{10}$ & & $\mathrm{MPN} / \mathrm{mL}$ & ${\mathrm{MPN} \log _{10}}$ \\
\cline { 3 - 6 } Cream & 1,700 & 3.23 & & 1,300 & 3.11 \\
Skim milk & 11 & 1 & & 6 & 0.8 \\
\hline
\end{tabular}




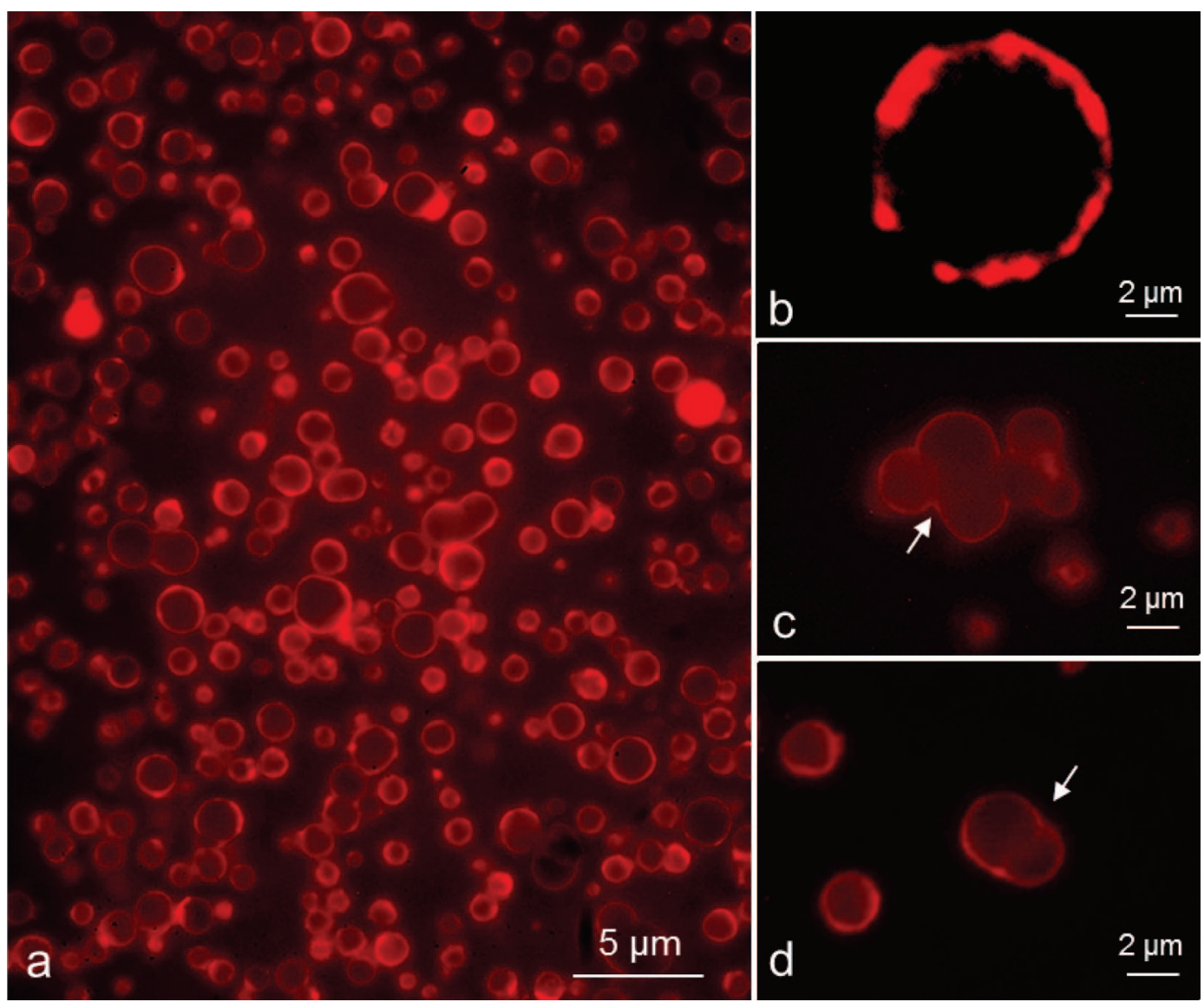

Figure 1. Fluorescent microscopy of milk fat globules stained with fluorescent probe DilC $18(3)$-DS (1,1'-dioctadecyl-3,3,3',3'tetramethylindocarbocyanine-5, $5^{\prime}$-disulfonic acid). The lipophilic probe is localized exclusively in the milk fat globule membrane (MFGM), which appears light against the dark background. (a) Cream obtained after overnight gravity separation of fat at $8^{\circ} \mathrm{C}$; (b) MFGM is heterogeneously stained, possibly due to different lipid composition or varying thickness; (c) and (d) persistent interactions among fat globules after cream dilution with skim milk (1:12); MFGM are often not visible in the contact area (arrows). Color version available online.

fluorescent area of MFGM or in the nonfluorescent area. However, because of the difficult separation of emission wavelengths of the 2 fluorochromes, it was impossible to address this question. Examination by TEM of replicates from freeze-fractured cream samples allowed us to observe adhesion of spores to fat globules (Figure 3 ). Because the rapid freezing allows a better sample preservation, the strength of the interaction established between these 2 particles was confirmed, albeit without adding further details concerning its nature.

To gain insight into this aspect, ultrathin sections were cut from resin-embedded contaminated cream samples and examined by TEM. The observation of numerous serial sections from 3 independent creaming experiments showed that, in most cases, adhesion of bacteria to fat globules was mediated by an amorphous, slightly electron-opaque material, sometimes granular in appearance (Figure 4, arrows). We detected adhesion to the thicker part of MFGM layers (Figure 4), corresponding to the bright fluorescent areas after stain- ing with $\mathrm{DilC}_{18}(3)$-DS. However, in some instances, bacteria were adhered where the MFGM was thinner (Figure 4a-c). The irregular thickness of MFGM is a well-known feature of fat globules, previously reported in studies that used different microscopy techniques (Buccheim, 1986; Evers, 2004; Robenek et al., 2006; Evers et al., 2008; Lopez et al., 2011).

Interestingly, bacteria cells at different stages of development, as well as endospores and free spores, can be observed by fluorescence microscopy. This situation is confirmed by literature data (Bergère and Hermier, 1970) showing that sporulation in Cl. tyrobutyricum is a very slow, multi-stage process. In some cases, bacteria adhered to single fat globules, linking them together (Figure 4a), which suggests that adhesion was strong enough to maintain stable contact between globules. From ultrathin sections of cream samples, we could see that, in some cases, adhesion of fat globules with each other implies a fusion of their MFGM (Figure 4b) that may correspond to a type of persistent interaction 

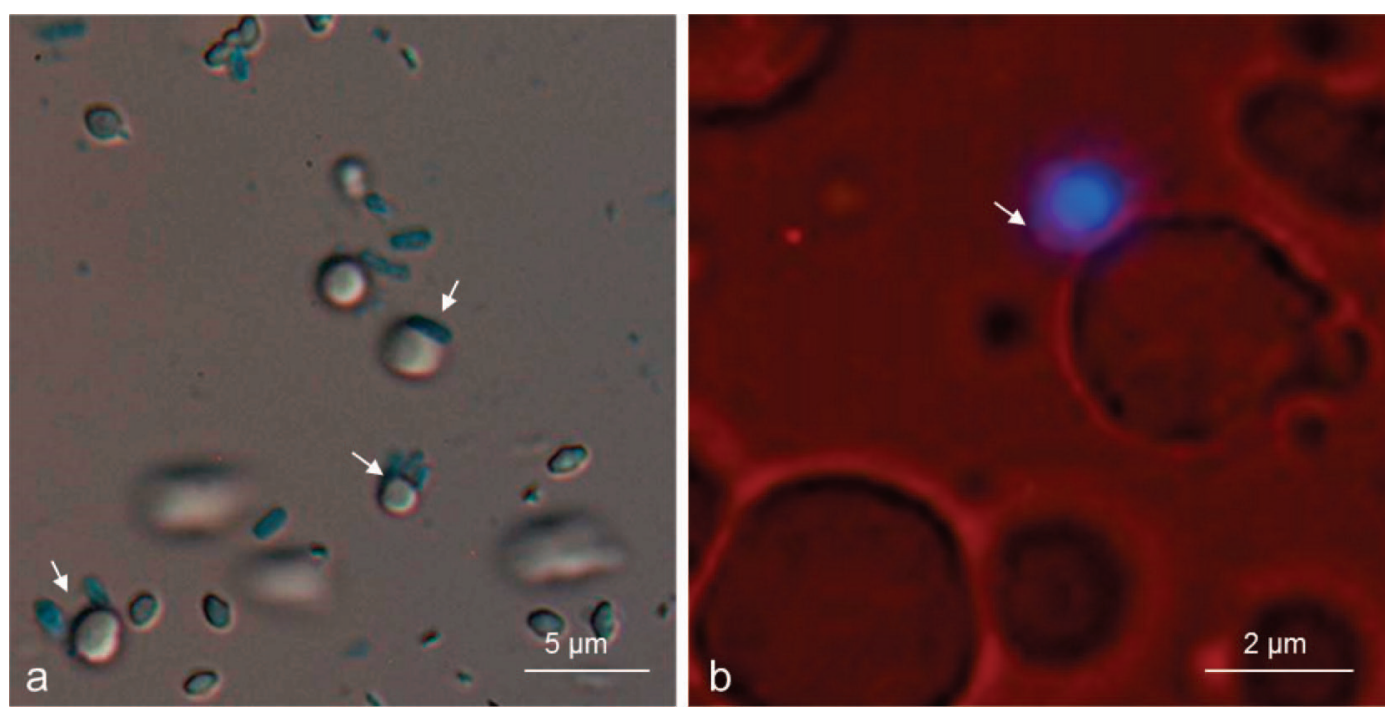

Figure 2. Cream obtained after natural creaming of milk contaminated with stained Clostridium tyrobutyricum spore suspension. (a) Light interference microscopy showing that most of the bacteria (dark gray) are tightly stuck to fat globules (arrows); (b) fluorescent microscopy of a spore stained with calcofluor (light against the dark background) adhering to a fat globule stained with the lipophilic probe $\mathrm{DilC} \mathrm{C}_{18}(3)$-DS (1,1'-dioctadecyl-3,3,3',3'-tetramethylindocarbocyanine-5,5'-disulfonic acid); the halo (arrow) around the spore is due to the bacterium containing it. Color version available online.

such as those observed by light fluorescence microscopy (Figure 1c and 1d). Numerous casein micelles are typically stuck to MFGM (Figures 4a-c; Zamora et al.,

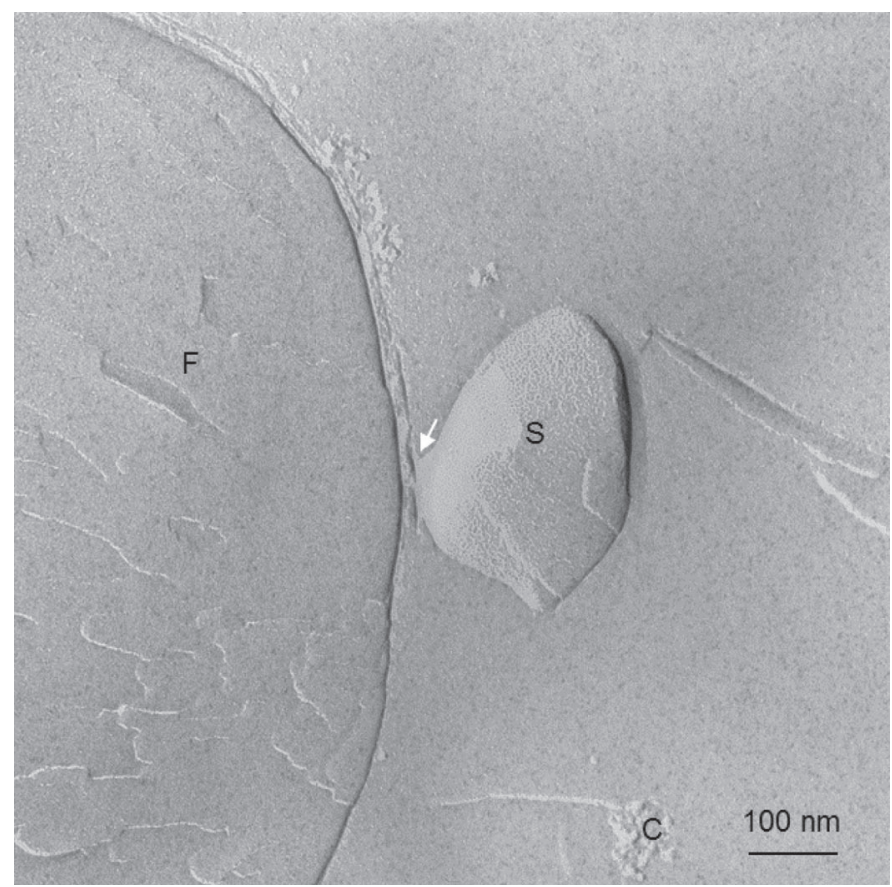

Figure 3. Transmission electron micrograph of freeze-fractured cream from natural creaming of milk contaminated with Clostridium tyrobutyricum spore suspension. Spore (S) adhering to a fat globule (F) membrane, possibly through a adhesion material (arrow); casein micelles (C) did not appear to be involved in the interaction.
2012), although they did not appear to be involved in bacterial adhesion.

\section{DISCUSSION}

The fat content of raw milk destined for manufacture of Grana Padano and Parmigiano-Reggiano cheeses must be lowered by natural creaming according to the product specification of these cheeses (European Union, 2011a,b). This process, which lasts for 8 to 12 $\mathrm{h}$ at temperatures between 8 and $20^{\circ} \mathrm{C}$, also allows the removal of the majority of microorganisms, spores, and somatic cells with the cream. Bottazzi and Zacconi (1980) reported that the debacterization obtained by natural creaming is quantitatively equivalent to but qualitatively better than that obtained with pasteurization, especially due to the removal of Clostridium spp. spores. It is commonly assumed that even very few spores remaining in the cheese curd may cause LBD. Thus, when the initial count of Clostridium spp. spores in milk is high, their removal by natural creaming can be insufficient to avoid development of LBD in cheese loaf. A better understanding of the mechanisms causing spores and bacteria to rise with milk fat globules was the major aim of the present work because such information may allow us to maximize the efficiency of spore removal.

The experimental procedure we adopted correctly reproduced the natural creaming phenomenon with high efficiency in spore removal $(>90 \%)$ after an overnight fat separation at $8^{\circ} \mathrm{C}$. The accuracy of the adopted 

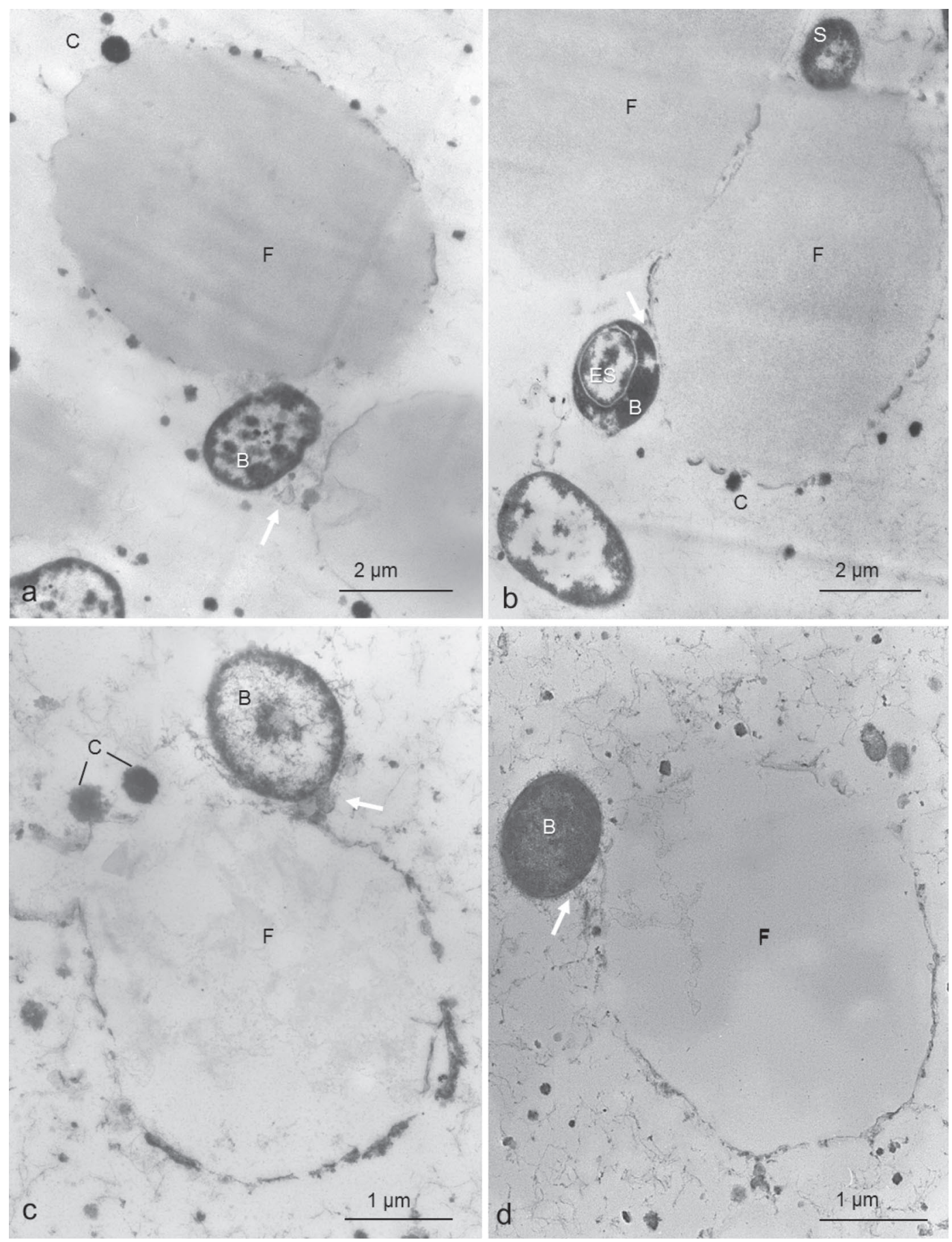

Figure 4. Transmission electron micrographs of ultrathin sections of cream from natural creaming of milk contaminated with a Clostridium tyrobutyricum spore suspension. Panels (a) to (d): bacteria (B) are stuck to fat globules (F) by an amorphous, slightly electron-opaque material (arrows). In some instances (a), bacteria (B) link fat globules (F) together; (b) Cl. tyrobutyricum may adhere to fat globules, either as a spore (S) or bacterial cell with or without the endospore (ES). C = casein micelles.

conditions in keeping the surface of fat globule intact was assessed by $\operatorname{DilC}_{18}(3)-\mathrm{DS}$ fluorescent staining. The MFGM was brightly but heterogeneously stained and the absence of fluorescence in some portions could be interpreted either as the lack of a lipid bilayer (Evers et al., 2008) or as the presence of co-existing fluid and gel phases that impair membrane staining. Recently, Lopez et al. (2011) suggested that local differences in the thickness of the MFGM could be due to the liquidordered domains of sphingomyelin with long-chain 
saturated fatty acids. This heterogeneous composition and complex structure of the MFGM are likely to affect both the persistent interactions among fat globules and the coalescence phenomena we have observed by light fluorescence microscopy (Figure 1c, d).

In regards to the supposed stable interaction between bacteria and fat globules in cream, light microscopy showed that this interaction does exist. In fact, most of the time, both spores and bacterial cells appeared firmly adherent to fat globules. This adhesion strength was confirmed by the fact that induced sample movement on microscope slide did not cause separation between the fat globule and bacteria (Figure 2a). However, the staining procedures for light and fluorescence microscopy did not yield information on the nature of this binding. The close adhesion of cells or spores to fat globules was confirmed by TEM examination of replicates of cryofixed cream. By this technique, spores seemed to adhere to MFGM (Figure 3) but, despite the high resolution, no molecules potentially involved in this mechanism could be visualized. More detail on the mechanism of adhesion came from examination of ultrathin sections by TEM. An electron-opaque amorphous material apparently adhering bacteria to MFGM, but not fat globules to themselves, appeared to be responsible for adhesion and hence for the bacteria rising during creaming (Figure 4). Thus, rising is not merely due to physical entrapment of bacteria in the fat clusters, as suggested by Rossi (1964), but to a more complex mechanism. Indeed, the involvement of milk immunoglobulins in the interactions among fat globules has been proposed for a long time, as suggested by the pioneering experiments of Bottazzi et al. (1972). In that regard, Bottazzi and Zacconi (1980) isolated from cream a proteinaceous material they called "active fraction" that was able to agglutinate fat globules or bacteria to themselves. This fraction proved to contain part of milk IgM; however, the contribution of other molecules was acknowledged (Zacconi and Bottazzi, 1982). $\beta$-Lactoglobulin and proteins from MFGM, such as Muc1 and peripheral proteins PAS 6/7, were reported to contribute to this phenomenon (Evers, 2008; Sando et al., 2009) but their role was only indirectly demonstrated because aggregation of fat globules was not observed in heat-treated milk. Honkanen-Buzalski and Sandholm (1981) showed that IgA and IgM were present on the surface of the MFGM, and Euber and Brunner (1984) demonstrated that gravity separation of fat did not occur in the absence of IgM (removed by a specific antiserum). More recently, indirect evidence of the involvement of immunoglobulins in bacterial adhesion to fat globules has come from the research by Barbano and collaborators (Ma and Barbano, 2000;
Caplan et al., 2013; Geer and Barbano, 2014a,b). They found that different levels of bacteria in milk influence the degree of gravity separation of fat but not of somatic cells (Caplan et al., 2013), suggesting that bacteria may compete for interactions with the immunoglobulins involved in gravity separation of the fat. As a consequence, high bacteria counts in milk may reduce the extent of creaming. However, the mechanism of immunoglobulin involvement in creaming is more complicated than first thought. Very recently, Geer and Barbano (2014b) found that the immunoglobulins themselves were not able to cause fat, bacteria, and spores to rise to the top of the milk; the presence of somatic cells was also necessary. However, in our microscopy studies, we did not observe somatic cells in contact with either the fat globules or bacteria; thus, it is possible that the contribution of the somatic cells to creaming is not necessarily a consequence of direct interactions and that other factors might be involved.

\section{CONCLUSIONS}

Although we cannot exclude that bacterial cells and spores rise to the top of the milk during natural creaming because of their physical entrapment among fat globules, our study shows for the first time that most of the bacteria are adhered to fat globules by an electron-opaque material, the nature of which has yet to be determined. Immunoglobulins are certainly the likely candidates responsible for the observed adhesion but other compounds (e.g., bacterial extracellular polysaccharides) might be involved. Biochemical and immunolocalization studies are underway to determine the composition of the adhesion material, information that is needed to set up protocols to maximize spore removal during creaming in Grana Padano and Parmigiano-Reggiano cheese making.

\section{ACKNOWLEDGMENTS}

This activity was developed within the FILIGRANA Project funded by the Italian Ministry of Agricultural, Food and Forestry Policies (MiPAAF D.M. 25741/7303/11, 1.12.11). The authors thank Hans Meisel (Max Rubner-Institut, Federal Research Institute of Nutrition and Food, Kiel, Germany) for kind hospitality in his department during part of our experimental work, Bruno Battistotti (University of Piacenza, Italy) for his valuable contribution in the interpretation of TEM micrographs, and Dario Maffi for technical assistance (Department of Agricultural and Environmental Sciences-Production, Landscape, Agroenergy, University of Milan). 


\section{REFERENCES}

Abo-Elnaga, G., N. H. Metwally, and M. El-Mansy. 1981. The bacterial content of creamed milk. Arch. Lebensmittelhyg. 32:19-21.

Bassi, D., F. Cappa, and P. S. Cocconcelli. 2009. A combination of a SEM technique and X-ray microanalysis for studying the spore germination process of Clostridium tyrobutyricum. Res. Microbiol. 160:322-329.

Bergère, J. L., and J. Hermier. 1970. Spore properties of Clostridia occurring in cheese. J. Appl. Bacteriol. 33:167-179.

Bergère, J. L., and J. Lenoir. 2000. Ripening Defects. Pages 484-506 in Cheese manufacturing accidents and cheese defects. Cheesemaking: From Science to Quality Assurance. 2nd ed. André Eck and Jean-Claude Gillis, ed. Lavoisier Publishing, Paris, France.

Bosi, F. G. Scolari, V. Bottazzi, and F. Dellaglio. 1984. Morfologia delle spore, DNA-DNA ibridizzazione e esami HCLP dei prodotti della fermentazione dei clostridi del formaggio grana. Sci. Tecn. Latt. Cas. 35:7-19.

Bottazzi, V. 1971. Sui fenomeni di agglutinazione nella preparazione del latte nel formaggio grana. Sci. Tecn. Latt. Cas. 22:253-273.

Bottazzi, V., and F. Dellaglio. 1970. Sulla presenza di spore di clostridi nel latte di produzione invernale e sulla comparsa di colonie di clostridi nel formaggio grana. Sci. Tecn. Latt. Cas. 21:59-72.

Bottazzi, V., F. Dellaglio, and P. G. Sarra. 1972. Affioramento del grasso ed agglutinazione dei microrganismi. Sci. Tecn. Latt. Cas. 23:287-304.

Bottazzi, V., and C. Zacconi. 1980. Isolamento e prima caratterizzazione del principio attivo nell'aggregazione dei globuli di grasso e de batteri. Sci. Tecn. Latt. Cas. 31:379-394.

Buchheim, W. 1986. Membranes of milk fat globules-Ultrastructural, biochemical and technological aspects. Kieler Milchw. Forsch. $38: 227-246$.

Caplan, Z., C. Melilli, and D. M. Barbano. 2013. Gravity separation of fat, somatic cells, and bacteria in raw and pasteurized milks. J. Dairy Sci. 96:2011-2019.

Cremonesi, P., L. Vanoni, T. Silvetti, S. Morandi, and M. Brasca 2012. Identification of Clostridium beijerinckii, Cl. butyricum, Cl. sporogenes, $\mathrm{Cl}$. tyrobutyricum isolated from silage, raw milk and hard cheese by a multiplex PCR assay. J. Dairy Res. 79:318-323.

Dellagio, F. J. Stadhouders, and G. Hup. 1969. Distribution of bacteria between the bottom, middle, and cream layers of creamed raw milk. Neth. Milk Dairy J. 23:140-145.

Euber, J. R., and J. R. Brunner. 1984. Reexamination of fat globule clustering and creaming in cow milk. J. Dairy Sci. 67:2821-2832

European Union. 2011a. Regulation no 584/2011, Approving non-minor amendments to the specification for a name entered in the register of protected designations of origin and protected geographical indications (Grana Padano (PDO)). OJ L 160 di 18.06.2011, 65-70.

European Union. 2011b. Regulation no 794/2011, Approving amendments to the specification for a name entered in the register of protected designations of origin and protected geographical indications (Parmigiano Reggiano (PDO)). OJ L 204 of 9.08.2011, 19-20.

European Union. 2012. Regulation no 1151/2012 of the European Parliament and of the Council on Quality Schemes for Agricultural Products and Foodstuffs. OJ 343 of 14.12.2012, 1-29.

Evers, J. M. 2004. The milk fat globule membrane-compositional and structural changes post secretion by the mammary secretory cell. Int. Dairy J. 14:661-674.

Evers, J. M. 2008. Novel analytical techniques for studying the milk fat globule membrane. PhD Thesis. Massey University, Palmerston North, New Zealand.

Evers, J. M., R. G. Haverkamp, S. E. Holroyd, G. B. Jameson, D. D. S. Mackenzie, and O. J. McCarthy. 2008. Heterogeneity of milk fat globule membrane structure and composition as observed using fluorescence microscopy techniques. Int. Dairy J. 18:1081-1089.

Frenyo, V. L., J. E. Butler, and A. J. Guidry. 1986. The association of extrinsic bovine IgG1, IgG2, SIgA and IgM with the major fractions and cells of milk. Vet. Immunol. Immunopathol. 13:239-254.

Geer, S. R., and D. M. Barbano. 2014a. Effect of colostrum on gravity separation of milk somatic cells in skim milk. J. Dairy Sci. 97:687-693.
Geer, S. R., and D. M. Barbano. 2014b. The effect of immunoglobulins and somatic cells on the gravity separation of fat, bacteria, and spores in pasteurized whole milk. J. Dairy Sci. 97:2027-2038.

Honkanen-Buzalski, T., and M. Sandhom. 1981. Trypsin-inhibitors in mastitic milk and colostrum: Correlation between trypsin in inhibitor capacity, bovine serum albumin and somatic cell contents. J. Dairy Res. 48:213-223.

Le Bourhis, A. G., J. Doré, J. P. Carlier, J. F. Chamba, M. R. Popoff, and J. L. Tholozan. 2007. Contribution of $\mathrm{Cl}$. beijerinckii and $\mathrm{Cl}$. sporogenes in association with $\mathrm{Cl}$. tyrobutyricum to the butyric fermentation in Emmental type cheese. Int. J. Food Microbiol. 113:154-163.

Lodi, R. 1990. The use of lysozyme to control butyric acid fermentation. Bull. Int. Dairy Fed. 251:51-54.

Lopez, C., V. Briard-Bion, O. Ménard, E. Beaucher, F. Rousseau, J. Fauquant, N. Leconte, and B. Robert. 2011. Fat globules selected from whole milk according to their size: Different compositions and structure of the biomembrane, revealing sphingomyelin-rich domains. Food Chem. 125:355-368.

Lopez, C., M. N. Madec, and R. Jimenez-Flores. 2010. Lipid rafts in the bovine milk fat globule membrane revealed by the lateral segregation of phospholipids and heterogeneous distribution of glycoproteins. Food Chem. 120:22-33.

Ma, Y., and D. M. Barbano. 2000. Gravity separation of raw bovine milk: Fat globule size distribution and fat content of milk fractions. J. Dairy Sci. 83:1719-1727.

Parham, P. 2009. Innate immunity: The induced response to infection. Pages 57-122 in The Immune System. 3rd ed. Garland Science, New York, NY.

Resmini, P., M. A. Pagani, and R. Prati. 1984. L'Ultrafiltrazione del latte nella tecnologia del Mascarpone. Sci. Tecn. Latt. Cas. $35: 213-230$.

Robenek, H., O. Hofnagel, I. Buers, S. Lorkowski, M. Schnoor, M. J. Robenek, H. Heid, D. Troyer, and N. J. Severs. 2006. Butyrophilin controls milk fat globule secretion. Proc. Natl. Acad. Sci. USA 103:10385-10390.

Rossi, J. 1964. Sul processo di caseificazione del formaggio grana. Latte 38:301-305.

Sando, L., R. Pearson, C. Gray, P. Parker, R. Hawken, P. Thomson, J. Meadows, K. Kongsuwan, S. Smith, and R. L. Tellam. 2009 Bovine Muc1: A polymorphic gene encoding a highly glycosylated mucin that protects epithelial cells from bacterial attachment. J. Dairy Sci. 92:5276-5291.

Schaeffer, A. B., and M. Fulton. 1933. A simplified method of staining endospores. Science 77:194.

Schmidt, D. G., and W. Buchheim. 1992. The application of electron microscopy in dairy research. J. Microsc. 167:105-121.

Silva, J. V. C., D. Legland, C. Cauty, I. Kolotuev, and J. Floury. 2015. Characterization of the microstructure of dairy systems using automated image analysis. Food Hydrocoll. 44:360-371.

Stadhouders, J. 1990a. Prevention of butyric acid fermentation by the use of nitrate. IDF Bull. 251:40-46.

Stadhouders, J. 1990b. Alternative methods of controlling butyric acid fermentation in cheese. IDF Bull. 251:55-98.

Stadhouders, J., and G. Hup. 1970. Complexity and specificity of euglobulin in relation to inhibition of bacteria and to cream rising. Neth. Milk Dairy J. 24:79-95.

van den Berg, G., W. C. Meijer, E. M. Düsterhöft, and G. Smit. 2004 Gouda and related cheeses. Pages 103-140 in Cheese: Chemistry, Physics and Microbiology, Vol. 2: Major Cheese Groups. 3rd ed. P. F. Fox, P. L. H. McSweeney, T. M. Cogan, and T. P. Guinee, ed. Elsevier Academic Press, London, UK.

Zacconi, C., and V. Bottazzi. 1982. Anticorpi ed aggregazione dei globuli di grasso del latte. Sci. Tecn. Latt. Cas. 33:1-14.

Zamora, A., V. Ferragut, B. Guamis, and A. J. Trujillo. 2012. Changes in the surface protein of the fat globules during ultra-high pressure homogenisation and conventional treatments of milk. Food Hydrocoll. 29:135-143. 